\title{
Analysis of Long-Term Performance of Geogrids by Considering Interaction among Reduction Factors
}

\section{감소계수 상호영향을 고려한 지오그리드의 장기성능 해석}

\author{
전 한 용 ${ }^{1} \quad$ Jeon, Han-Yong \\ 김 원 춘 ${ }^{2} \quad$ Kim, Yuan-Chun \\ 장 연 수 $^{3} \quad$ Jang, Yeon-Soo
}

\begin{abstract}
요지
지오그리드의 장기허용강도를 산출할 때 사용되는 총 감소계수는 내시공성 감소계수 $\left(\mathrm{RF}_{\mathrm{ID}}\right)$, 내화학성 감소계수 $\left(\mathrm{RF}_{\mathrm{D}}\right)$, 크리프 감소계수 $\left(\mathrm{RF}_{\mathrm{CR}}\right)$ 등이 적용된다. 지오그리드의 단기인장강도에 대한 감소계수를 고려한 허용인장강도 산출 모델의 경우 감소계수들 사이의 상호 작용력을 고려하지 않는 한계를 가지고 있다. 접점강도는 인장강도와 마찬 가지로 시공 시 손상이나 화학적 분해에 의하여 감소하게 된다. 기존의 단일접점강도 시험 방법은 치수효과를 고려할 수 없기에 결과의 편차가 큰 시공 시 손상된 시험편의 접점강도를 측정하는데 적합하지 않다. 또한 시공 시 손상에 의한 전단강도 변화에 대한 연구도 전혀 이루어지지 않은 실정이다. 따라서 본 연구에서는 다양한 조건을 고려하여 지오그리드의 장기성능에 영향을 미치는 감소계수들을 재평가하고 감소계수 사이의 상호 작용을 고려하여 정확한 장기허용강도를 구하려고 한다. 내시공성 시험과 내화학성 시험 후 크리프 시험결과 총 감소계수는 GRI GG-4 시험 값보다 작게 나타났다. 내시공성 시험과 내화학성 시험 후 접점강도의 감소계수는 인장강도 감소계수보다 더 작게 나타났다. 내시공성 시험후 전단강도 차이가 나타나지 않거나 증가함을 나타내었다
\end{abstract}

\begin{abstract}
Total reduction factor that is used when calculating allowable tensile strength of geogrids is made by multiplying the installation damage reduction factor $\left(\mathrm{RF}_{\mathrm{ID}}\right)$, chemical degradation reduction factor $\left(\mathrm{RF}_{\mathrm{D}}\right)$, and creep reduction factor $\left(\mathrm{RF}_{\mathrm{CR}}\right)$ etc. In case of a model estimating allowable tensile strength considering reduction factor over the short-term tensile strength of geogrids, it has a limit of not considering interaction force between reduction factors. Junction strength comes to be reduced by installation damages or chemical degradation in the same way as tensile strength. Single junction test method cannot properly test damaged samples and shows large deviations as it does not consider scale effect. Besides, regarding calculating shear strength, no reasonable study on reduction factors was conducted yet. Therefore, in this study, reduction factors that may affect the long-term performance of geogrids were revaluated considering various conditions and accurate long-term allowable tensile strength was calculated considering interrelation between reduction factors. Creep results after installation damage and chemical resistance test showed lower value than calculated value according to GRI GG-4. After the installation damage test and the chemical resistance test, the reduction factor of junction strength was less than that of tensile strength. Shear strength before and after installation damage showed no change or increase.

1 정회원, 인하대학교 나노시스템공학부 교수 (Member, Prof., Dept. of Nano-Systems Engrg., Inha Univ., Tel: +82-32-860-7492, Fax: +82-32-872-1426, hyjeon@inha.ac.kr, 교신저자)

2 정회원, 인하대학교 나노시스템공학부 박사후 연구원 (Member, Post-Doc., Dept. of Nano-Systems Engrg, Inha Univ.)

3 정회원, 동국대학교 사회환경시스템공학부 교수 (Member, Prof, Dept. of Civil and Env. Engrg., Dongguk Univ.)

* 본 논문에 대한 토의를 원하는 회원은 2013년 1월 31일까지 그 내용을 학회로 보내주시기 바랍니다. 저자의 검토 내용과 함께 논문집에 게재하여 드립니다.
\end{abstract}


Keywords : Interrelation between reduction factors, Junction strength, Long-term performance, Shear strength, Total reduction factor

\section{Introduction}

In the last thirty years, the use of geosynthetics has been continuously increased in different civil and environmental engineering applications such as reinforced slopes, retaining walls, embankments, and waste containments. The analysis method and design theory have developed little compared with its engineering application. And, the inherent margin, in accordance with poor performance with respect to internal stability, has not been quantified in a systematic manner (Koerner, R.M, 2005). A great number of permanent geosynthetic-reinforced soil structures were constructed due to their high cost -effectiveness and stability. Nevertheless, it should be admitted that geosynthetic-reinforced soil structures, including walls and abutments, are not as stiff as steelreinforced concrete structures. Therefore, it is of paramount importance to become capable of accurately predicting the exact deformation by long-term sustained and cyclic loading, develop a relevant and rational design procedure taking into account the viscous property of geosynthetic reinforcement and develop a method that can effectively reduce the residual deformation by long-term sustained and cyclic loading and various construction conditions (Berg, R.R., Allen and Bell, J.R, 1998; Lawson, C.R, 1986; Task Force \#27, 1991; Zornberg, J.G. and Mitchell, J.K, 1994).

T.M. Allen and R.J. Bogangto Bathurst (2002) demonstrate, through back-analysis of available wall case histories, that geosynthetic reinforcement load levels appear to be significantly lower than values estimated using the North American design methods. The cause of conventional design results from consideration of a safety factor in terms of civil engineering and uncertainty of short-term and long-term properties of materials. Uncertainty of material comes from combination of each factor that may change the total reduction factor. So, if total reduction factor is calculated considering combination of each factor would certainly reduce uncertainty and thus save cost. There are not many previous studies on installation damage test and combination effect. Since the composite behavior for installation damage and creep strain is very difficult to be analytically quantified the constant trend is not established even in a formula of a standardized function or empirical laws. According to the study of Allen, T.M and Bathurst, R.J. (1996), the long-term behavior of damaged geogrids upon construction showed the decreasing result based on isochronous curve. On the other hand, Billing, J.W. et al. (1990) studied creep behavior of PP woven textile, geostrip and HDPE geogrid after installation damage; and in case of PP woven geotextile, they reported that it showed relatively a little creep strain compared to a specimen before damage. Besides, in case of geostrip, it was reported that it almost never showed installation damage by PP coating which is a characteristic of the product. Cho, S.D. et al. (2006) evaluated installation damage at maximum particles of 40,60, $80 \mathrm{~mm}$, and then among them, assessed creep characteristics of some specimens. As the size of filling material is larger, reduction factor of installation damage was represented to be larger. However, the studies on creep characteristics according to maximum particle size have not been conducted. Up to now, the creep test by damaged specimens upon construction focused on only a variety of geosynthetics materials or construction conditions and the studies on variation of reduction factor by characteristics of soil have never been implemented. Besides, the studies on the effect of chemical degradation on creep characteristics have not been conducted either.

As in the theory of tensile property mentioned above, the decrease of the allowable junction strength depends on short-term effects like installation damage, which reduce the maximum junction strength but do not further affect the long-term properties and on effects like creep 
and aging by hydrolysis, oxidation and/or abrasion, which result in long-term junction strength loss. In the second case, the estimated reduction depends on the design life time. The reduction factor of junction strength is different from tensile strength due to the difference in physical and chemical structure. Therefore, correct junction strength reduction factor is the key point to calculate allowable junction strength. Hsieh, C. et. al. (2000) evaluated junction strength of PET geogrids after installation damage using GRI GG-2 test method. Installation damage test uncertainty is large and damage on each specimen will be different. But, GRI GG-2 test method does not consider scale effect that creates large deviation in the test results and lowers the accuracy. To the evaluation of the tensile strength of damaged geogrid, wide-width tensile strength test method is used. Hence, multi junction test method is more appropriate to the evaluation of junction strength of damaged geogrid considering the scale effect and thus uncertainty of results can be reduced. Moreover, effect of chemical degradation on junction was not researched before.

By the way, in the case of installation of geogrids on site, the design model regarding the strength reduction according to the installation damages was suggested but any definite model for the change of shear behavior according to the occurring changes upon installation was not suggested. Especially, since the shear property is an important factor that determines the long-term performance of civil structures in case of the slope reinforcement, the design model that predicted the change of performance considering the damages by compacting work and equipment upon construction must be suggested. Therefore, considering the damage of geogrids that inevitably occurs upon construction on site, a proper model for the construction conditions on site must be applied.

In this study, the effect of installation damage and chemical degradation on creep characteristics was comprehensively reviewed and then its value was compared with GRI GG-4 test value. Moreover, effect of installation and chemical degradation on junction strength was evaluated using multi-junction clamp and change of shear behavior was evaluated before and after installation damage.
The purpose of this experiment is to reduce uncertainty of allowable tensile strength by suggesting precise reduction factor considering complex effects and to reflect this in the design properly.

\section{Experiment}

\subsection{Preparation of Geogrids}

For the samples to be used for this experiment, three kinds of geogrids were used such as woven type, warp knitted type and welded type, and the design strength was $6 \mathrm{~T}, 8 \mathrm{~T}$ and 10T respectively. The yarn of all geogrids is polyethylene terephthalate (PET) and the coating material of woven geogrid and warp knitted geogrid is polyvinyl chloride (PVC). But the coating material of welded geogrid is polypropylene (PP). Figure 1 shows a picture of the geogrid used in this study. And the specification and physical properties of geogrids were represented in Table 1.

2.2 Interaction among Reduction Factors $\left(\mathrm{RF}_{\mathrm{CR}}, \mathrm{RF}_{\mathrm{ID}}\right.$, $\left.\mathrm{RF}_{\mathrm{D}}\right)$

Installation damage of geogrids was evaluated with compact condition in laboratory. Filling materials were divided by sieves and particle size of $(0-0.5 \mathrm{~mm}$, soil $)$

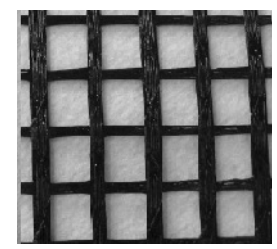

(a) Woven geogrid

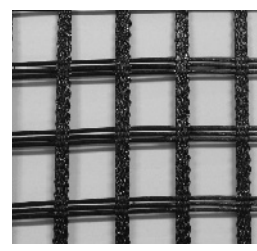

(b) Warp-knitted geogrid

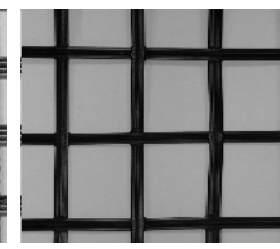

(c) Welded geogrid
Fig. 1. Photograph of geogrids used in this study

Table 1. Specifications of geogrids

\begin{tabular}{c|c|c|c}
\hline \multirow{2}{*}{ Geogrid } & \multirow{2}{*}{$\begin{array}{c}\text { Raw Material } \\
\text { /Coating } \\
\text { polymer }\end{array}$} & \begin{tabular}{c} 
Mechanical properties (ASTM D 4595) \\
\cline { 3 - 4 } \\
\cline { 3 - 4 } \\
strength (ton/m)
\end{tabular} & $\begin{array}{c}\text { Elongation } \\
\text { at Break (\%) }\end{array}$ \\
\hline WG-8 & PET/PVC & 10.1 & 10.7 \\
\hline WKG-8 & PET/PVC & 10.8 & 11.9 \\
\hline WBG-6 & PET/PP & 7.9 & 11.1 \\
\hline WBG-8 & PET/PP & 10.8 & 11.9 \\
\hline
\end{tabular}


and (4.75 - $37.5 \mathrm{~mm}$, gravel) were selected for installation damage test individually. The experiment was conducted in accordance to ENV ISO 10722-1 and load cycle was taken 200 .

Original and installation damaged geogrids were immersed in closed beakers in $\mathrm{NaOH}(\mathrm{pH} 9$ and $\mathrm{pH}$ 13) buffer solutions. Then, beakers were placed in temperature -controlled ovens. A sample was collected at each month, the single rib tensile strength was measured, and the chemical resistance was evaluated.

Creep test were performed on the original geogrids, installation damaged geogrids and installation damaged with the chemical treated geogrids. Accelerated creep tests were performed on woven geogrids using the accelerated creep test equipment. The load levels of 50 - 78\% ultimate tensile strength were applied to woven geogrids. Each specimen was allowed to reach equilibrium at $20^{\circ} \mathrm{C}$ prior to test initiation. Temperature was stepped up by $14^{\circ} \mathrm{C}$ every 10000 seconds starting $20^{\circ} \mathrm{C}$ and ending to $76^{\circ} \mathrm{C}$. Creep strains for the geogrids are plotted versus $\log$ time at each level of temperatures.

\subsection{Junction Strength Test}

Junction strength tests of original geogrids, installation damaged geogrids and installation damaged with the chemical treated geogrids were performed using multi-junction clamp according to ASTM D4595.

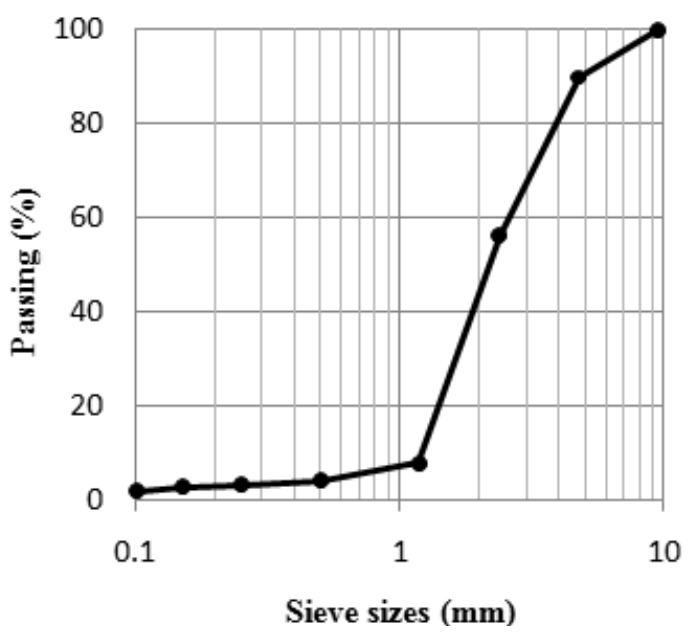

Fig. 2. Grain size distribution of test soils

\subsection{Direct Shear Test}

The filling material that was used for the direct shear test was soil from the real construction site, and Figure 2 shows grain size distribution of the filling material. The soil used for the filling material is classified into SP (poorly graded sand) by unified soil classification system, and the direct shear strength was measured at each interface by using the medium-scaled direct shear test device on the basis of ASTM D5321.

\section{Result and Discussion}

3.1 Combination Effect among $\mathrm{RF}_{\mathrm{CR}}, \mathrm{RF}_{\mathrm{ID}}, \mathrm{RF}_{\mathrm{D}}$

Figures $3-4$ show the percentage of tensile strength

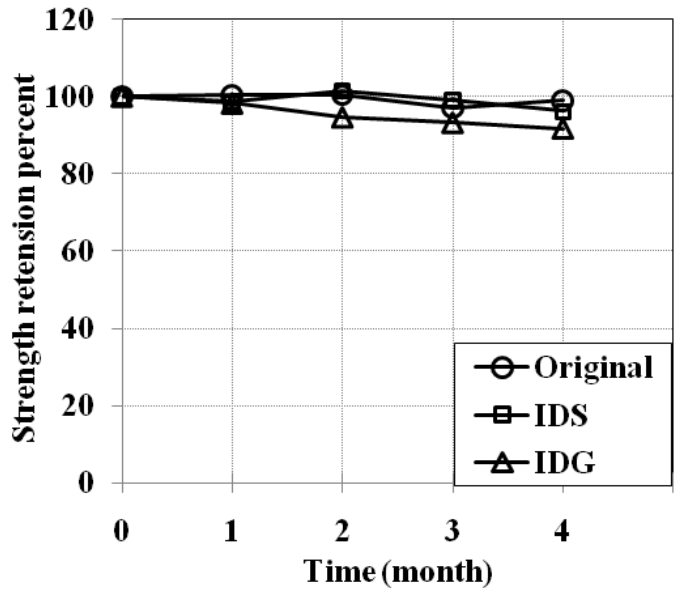

Fig. 3. Rib tensile strength retention percent of WG-8 with exposure conditions $\left(\mathrm{pH} 9,50^{\circ} \mathrm{C}\right)$

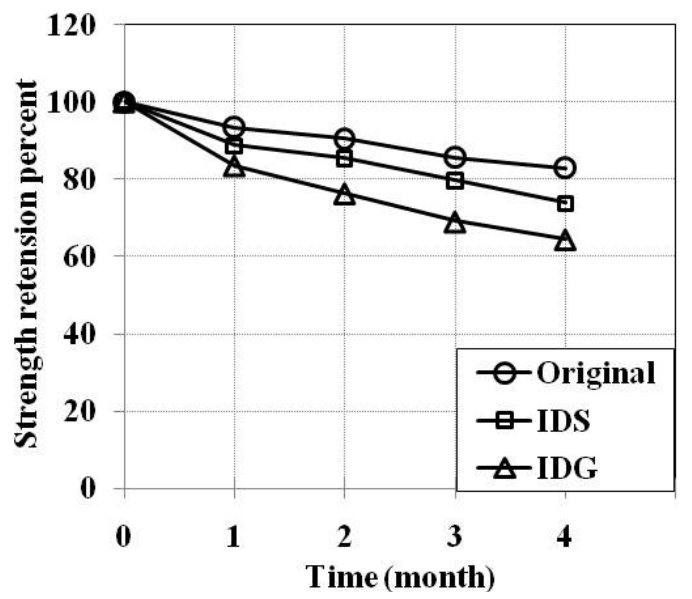

Fig. 4. Rib tensile strength retention percent of WG-8 with exposure conditions ( $\mathrm{pH} 13,50^{\circ} \mathrm{C}$ ) 
retention of WG-8 after different chemical exposure. There was merely small amount of decrease in original and specimen of installation damage in filling soil (IDS) after exposure to $\mathrm{pH}$ 9. In contrast, there was decrease in specimen of installation damage in gravel (IDG) at $\mathrm{pH}$ 9. This is caused by PVC coating material destroyed during installation test and PET filament directly exposed to solutions and degraded chemically. It maybe a problem if continuous chemical degradation occurs on geogrids as it is expected that service life of geogrid's is $50-100$ years. Since WG- 8 showed less than $10 \%$ decrease in extreme condition $\left(\mathrm{pH} 9,50^{\circ} \mathrm{C}\right.$, and installed in gravel), it can be predicted that in real environment chemical degradation followed by installation damage is very limited. Moreover, it hardly reaches to the activation energy for chemical degradation as temperature in reinforcement wall is usually lower than $20^{\circ} \mathrm{C}$. But in some specific conditions, like slope of landfills, the temperature may over $50^{\circ} \mathrm{C}$. It may require caution to use geogrids at high alkali condition and more time is needed to evaluate chemical degradation properly. The tensile strength decreased much in severe alkaline condition $\mathrm{pH} 13$. Especially IDG showed tensile strength retention of $64.4 \%$.

Under the condition of $\mathrm{pH} 9,50^{\circ} \mathrm{C}$, creep characteristic of WG- 8 that was exposed for 4 months was represented (Table 2 and Figure 5). In cases of $50 \%$ and $60 \%$ of ulti- mate tensile strength (UTS), they shows the stable behavior during test period, there was not a rupture in the case of $65 \%$, but it showed strain exceeding $7.5 \%$ that is a limited strain. There were creep rupture in cases of $68 \%$ and $75 \%$. Compared with creep characteristic of original geogrid, it showed almost similar strain under the same load. Therefore, it could be known that there was little change of creep characteristic after chemical exposure.

Tables 3-4 and Figures 6-7 show the resulting creep properties of the WG-8 after installation damage. After installation damage, the value of creep strain is higher

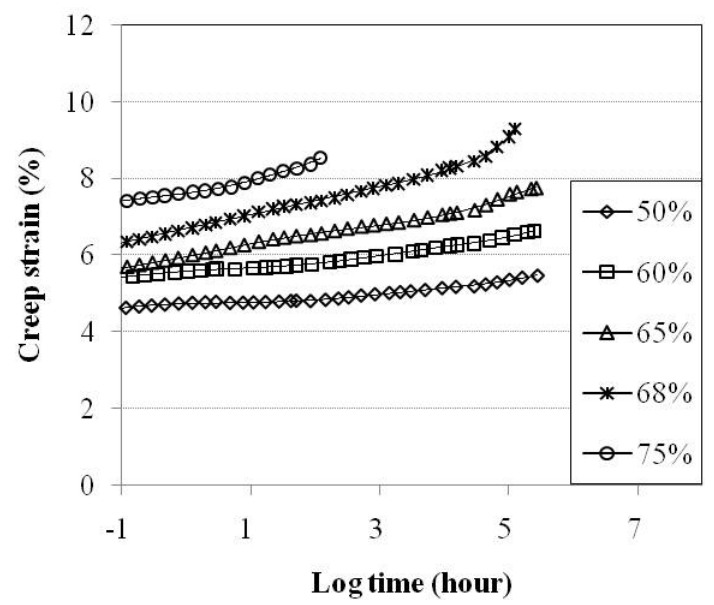

Fig. 5. Tensile creep master curve of WG-8 after chemical exposure (pH 9, $50^{\circ} \mathrm{C}, 4$ months)

Table 2. Results of creep test after chemical exposure $\left(\mathrm{pH}=9,50^{\circ} \mathrm{C}, 4\right.$ months)

\begin{tabular}{c|c|c|c|c|c}
\hline \multirow{2}{*}{ Specification } & \multicolumn{5}{|c}{ Applied stress (\% of UTS) } \\
\cline { 2 - 6 } & 50 & 60 & 65 & 68 & 75 \\
\hline Log time (hour) & 5.45 & 5.30 & 5.35 & 5.10 & 2.09 \\
\hline Elongation (\%) & 5.49 & 6.60 & 7.72 & 9.30 & 8.55 \\
\hline Condition & \multicolumn{7}{|c}{ Continued } \\
\hline
\end{tabular}

Table 3. Results of creep test after installation damage by filling soil

\begin{tabular}{c|c|c|c|c|c}
\hline \multirow{2}{*}{ Specification } & \multicolumn{5}{|c}{ Applied stress (\% of UTS) } \\
\cline { 2 - 6 } & 50 & 60 & 65 & 72 & 75 \\
\hline Log time (hour) & 5.45 & 5.79 & 4.98 & 2.21 & 8.62 \\
\hline Elongation (\%) & 6.32 & 7.99 & 8.98 & 8.95 & \multicolumn{3}{c}{ Creep rupture } \\
\hline Condition & \multicolumn{2}{|c|}{ Continued }
\end{tabular}

Table 4. Results of creep test after installation damage by gravel

\begin{tabular}{c|c|c|c|c}
\hline \multirow{2}{*}{ Specification } & \multicolumn{4}{|c}{ Applied stress (\% of UTS) } \\
\cline { 2 - 5 } & 50 & 60 & 62 & 70 \\
\hline Log time (hour) & 5.49 & 4.65 & 4.12 & 1.15 \\
\hline Elongation (\%) & 7.46 & 8.83 & 9.6 & 8.97 \\
\hline Condition & Continued & \multicolumn{3}{|c}{ Creep rupture } \\
\hline
\end{tabular}


than that without installation damage at the same load. This is because some of the filaments are so greatly damaged or torn by the installation damage that the remaining filaments suffered higher load than usual. In case of IDS, it showed stable behavior during test periods of $50 \%$ and $60 \%$ of UTS, and there was creep rupture

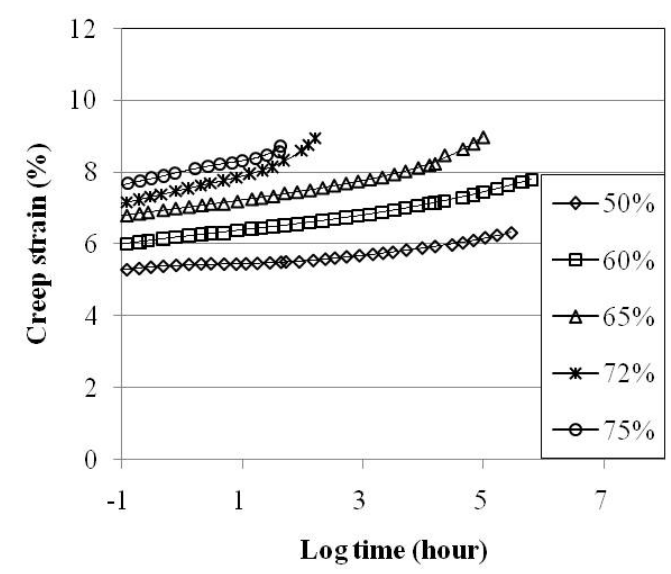

Fig. 6. Tensile creep master curve of WG-8 after installation damage by filling soil

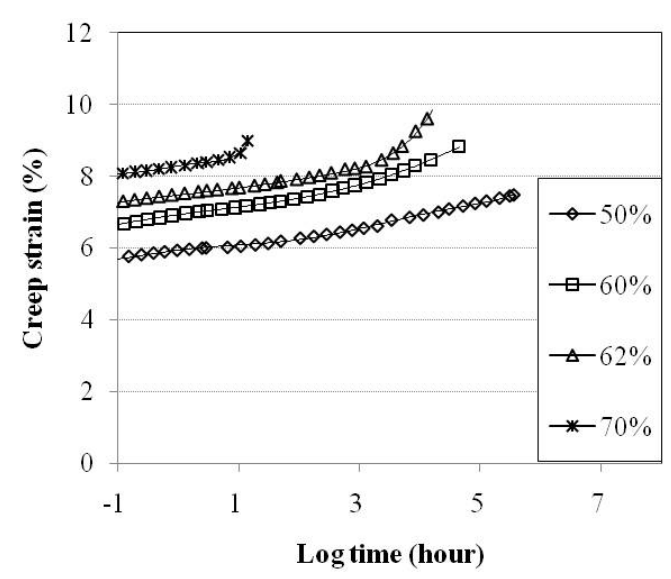

Fig. 7. Tensile creep master curve of WG-8 after installation damage by gravel under the load more than $65 \%$. On the other hand, in case of IDG, it showed stable behavior only at $50 \%$ of UTS and there was creep rupture under the load more than $60 \%$.

Tables 5-6 and Figures 8-9 show the resulting creep properties of the WG- 8 after installation damage and

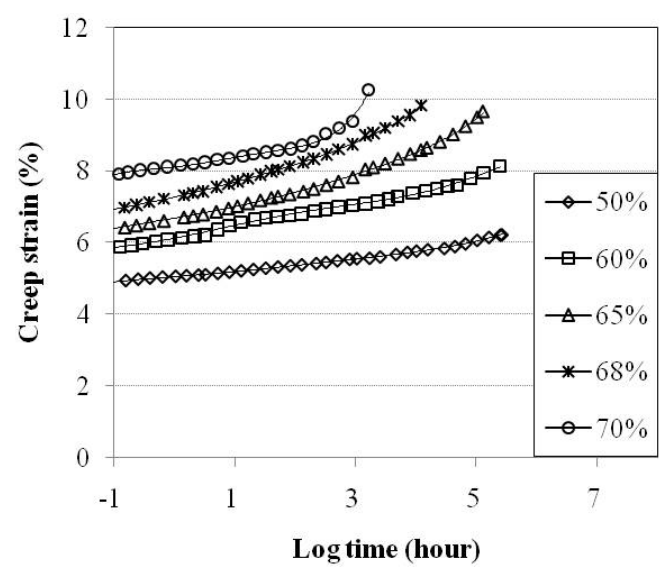

Fig. 8. Tensile creep master curve of WG-8 after installation damage and chemical exposure $\left(\mathrm{pH} 9,50^{\circ} \mathrm{C}\right.$, soil)

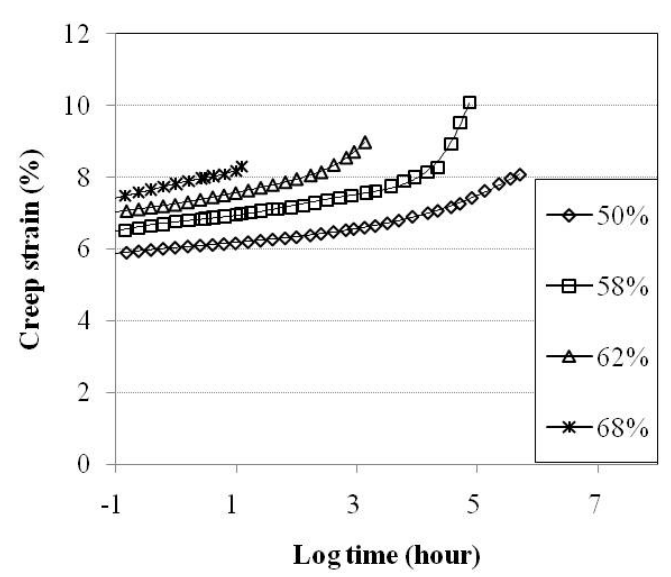

Fig. 9. Tensile creep master curve of WG-8 after installation damage and chemical exposure $\left(\mathrm{pH}=9,50^{\circ} \mathrm{C}\right.$, gravel)

Table 5. Results of creep test after installation damage and chemical exposure $\left(\mathrm{pH} 9,50^{\circ} \mathrm{C}\right.$, soil)

\begin{tabular}{c|c|c|c|c|c}
\hline \multirow{2}{*}{ Specification } & \multicolumn{5}{|c}{ Applied stress (\% of UTS) } \\
\cline { 2 - 6 } & 50 & 60 & 65 & 68 & 70 \\
\hline Log time (hour) & 5.40 & 5.39 & 5.01 & 4.09 & 3.21 \\
\hline Elongation (\%) & 6.22 & 8.15 & 9.67 & 9.82 & 10.27 \\
\hline Condition & \multicolumn{2}{|c}{ Continued } & \multicolumn{3}{c}{ Creep rupture } \\
\hline
\end{tabular}

Table 6. Results of creep test after installation damage and chemical exposure (pH 9, $50^{\circ} \mathrm{C}$, gravel)

\begin{tabular}{c|c|c|c|c}
\hline \multirow{2}{*}{ Specification } & \multicolumn{4}{|c}{ Applied stress (\% of UTS) } \\
\cline { 2 - 5 } & 50 & 60 & 65 & 68 \\
\hline Log time (hour) & 5.71 & 4.87 & 3.14 & 1.09 \\
\hline Elongation (\%) & 8.07 & 10.09 & 8.98 & 8.30 \\
\hline Condition & Continued & \multicolumn{3}{|c}{ Creep rupture } \\
\hline
\end{tabular}


chemical degradation. The experiment result turned out to be similar to the case considering only installation damage. In case of IDS, it showed stable behavior during test periods of $50 \%$ and $60 \%$ of UTS and there was creep rupture under a load more than $65 \%$. On the other hand, in case of IDG, it showed stable behavior under only $50 \%$ of UTS and there was creep rupture at $58 \%$ of UTS as well. From this, it can be known that the effect of chemical exposure condition $\left(4\right.$ months, $\left.50^{\circ} \mathrm{C}\right)$ on creep characteristic was limited.

Figures 10-12 show isochronous curve at each condition, and Figures 13 - 14 show each regression analysis diagram, and the calculated reduction factors were represented in Tables $7-8$. There was no change in reduction factors i.e. combination of $\mathrm{RF}_{\mathrm{D}}$ and $\mathrm{RF}_{\mathrm{CR}}$. This is caused by good chemical resistance in $\mathrm{pH}$ 9. Also, there was no change in combination of $\mathrm{RF}_{\mathrm{ID}}$ (soil) and $R F_{\mathrm{D}}$. But tested value is higher than calculated value in the combination of $\mathrm{RF}_{\mathrm{ID}}$ (gravel) and $\mathrm{RF}_{\mathrm{D}}$. This is due to the destroyed surface of coating materials by gravel and accelerated chemical degradation. However, the difference is not too much. The tested reduction factor is lower than the calculated value in the combination of $\mathrm{RF}_{\mathrm{ID}}$ and $\mathrm{RF}_{\mathrm{CR}}$, especially at gravel, lower than $12 \%$. This is caused by mutual effect of installation damage and creep test. The same is applicable for the total reduction factor.

\subsection{Interpretation of the Geogirds Junction Strength by Installation Damage and Chemical Degradation}

A summary of the results of the tensile strength and junction strength before and after installation damage in gravel are presented in Table 9. After installation damage, the tensile strength of geogrids was significantly reduced. Especially, the tensile retention \% of WKG-8 from cross-machine direction (CMD) was 67.7. This tells that since the transverse rib of WKG- 8 is weak, more damage can be caused by installation damage. In contrast, the tensile retention \% of WG- 8 from CMD showed larger value compared to machine direction (MD). This is due to the fact that transverse rib of WG- 8 has thicker bundle diameter and coating compared to WKG-8. In case of junction strength, the retention \% of WG- 8 and WKG-8 showed relatively large values of 100 and $89 \%$ respectively. This is caused by the fact that the junction failure mechanism of woven geogrid is pulled out. So, the tensile reduction in transverse rib does not affect the junction damage. In contrast, junction failure mechanism of warp knitted geogrid is caused by the self-rupture of cross rib. Therefore tensile strength of transverse rib and

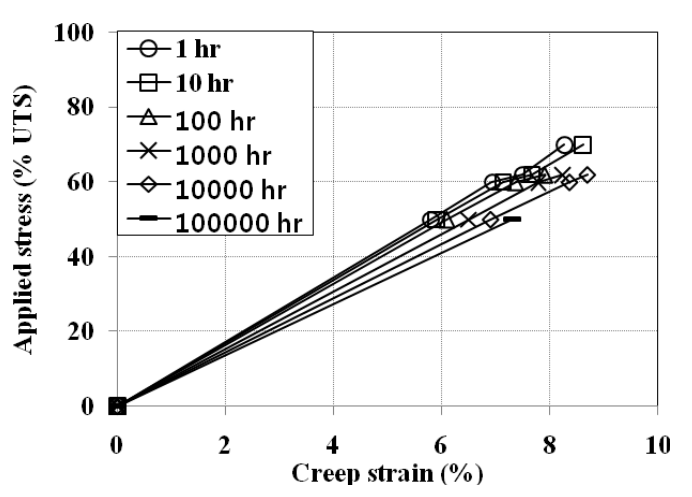

Fig. 10. Isochronous curve of WBG- 6 after installation damage in gravel

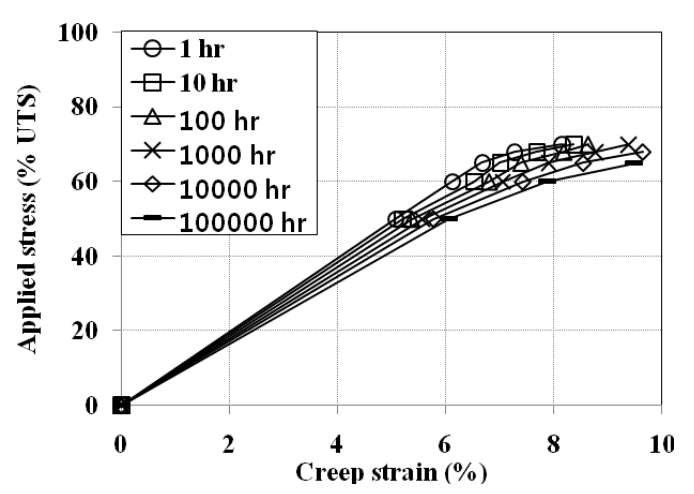

Fig. 11. Isochronous curve of WBG-6 after installation damage in soil and chemical exposure

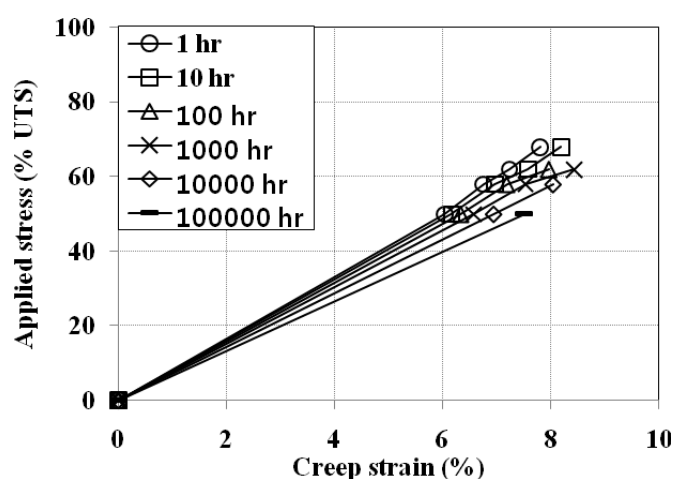

Fig. 12. Isochronous curve of WBG-6 after installation damage in gravel and chemical exposure 
bending force are mainly determined by junction strength.

Table 10 shows the reduction factors calculated from the retained tensile and junction strength after installation damage and chemical exposure. For both of woven and warp knitted geogrids, reduction factor in junction strength test showed lower value than that in tensile strength test. Especially in woven geogrid the value of junction strength reduction factor is negligible because of pull-out mechanism.

3.3 Interpretation of Shear Behavior of Geogrids through Index Installation Damage Testing

Figures 15-16 show the shear behaviors of original geogrids. According to the results of all tests, the peak strength was indicated at shearing displacement within 30 $\mathrm{mm}$ but there was more or less difference in the behavior of post-peak strength. The post-peak strength of two geogrids at normal stress of 50,100 $\mathrm{kPa}$ relatively remains to be constant after reduction but it represented a phenomenon that the post-peak strength of two geogrids

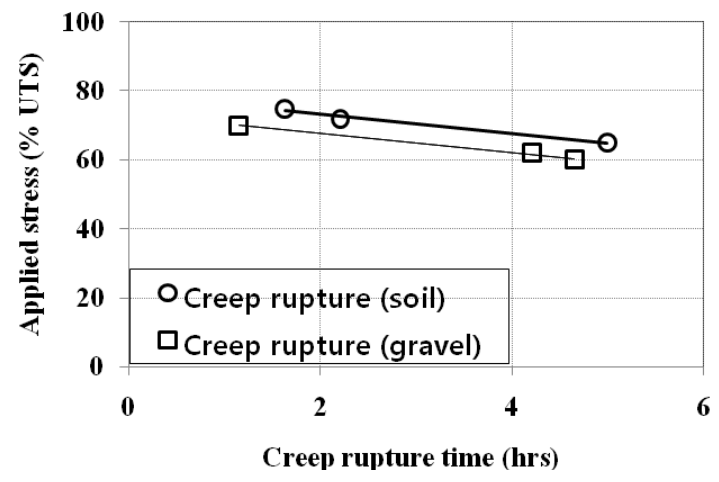

Fig. 13. Plot of applied stress vs. creep rupture time of geogrid considered installation damage

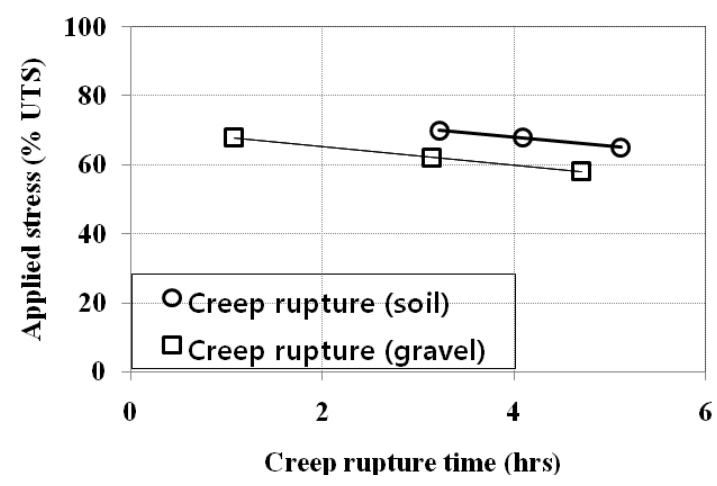

Fig. 14. Plot of applied stress vs. creep rupture time of geogrid considered installation damage and chemical degradation at normal stress of $150 \mathrm{kPa}$ continuously reduced and it showed the behavior that the peak strength increased as normal stress increased. Figures 17-18 show the shear behavior after installation damage test. After installation damage test, the shear behavior of geogrids was different from the one before the test. Compared to the status before installation damage test, there was no obvious peak strength at a specimen after installation damage test. According to the results of all tests, the shear strength showed rapidly increasing behavior up to the shear displacement within $20 \mathrm{~mm}$ and subsequently, it showed continuously and steadily increasing behavior.

Tables 11 - 12 show the shear stress according to nor-

Table 7. Reduction factor of geogrids at $\mathrm{pH} 9,10^{6}$ hours (soil)

\begin{tabular}{c|c|c}
\hline Reduction factor & Calculated & Tested \\
\hline $\mathrm{RF}_{\mathrm{D}}, \mathrm{RF}_{\mathrm{CR}}$ & 1.54 & 1.55 \\
\hline $\mathrm{RF}_{\mathrm{ID}}, \mathrm{RF}_{\mathrm{D}}$ & 1.1 & 1.1 \\
\hline $\mathrm{RF}_{\mathrm{ID}}, \mathrm{RF}_{\mathrm{CR}}$ & 1.69 & 1.61 \\
\hline $\mathrm{RF}_{\mathrm{ID}}, \mathrm{RF}_{\mathrm{CR}}, \mathrm{RF}_{\mathrm{D}}$ & 1.69 & 1.59 \\
\hline
\end{tabular}

Table 8. Reduction factor of geogrids at $\mathrm{pH} 9,10^{6}$ hours (gravel)

\begin{tabular}{c|c|c}
\hline Reduction factor & Calculated & Tested \\
\hline $\mathrm{RF}_{\mathrm{D}}, \mathrm{RF}_{\mathrm{CR}}$ & 1.54 & 1.55 \\
\hline $\mathrm{RF}_{\mathrm{ID}}, \mathrm{RF}_{\mathrm{D}}$ & 1.28 & 1.35 \\
\hline $\mathrm{RF}_{\mathrm{ID}}, \mathrm{RF}_{\mathrm{CR}}$ & 1.97 & 1.76 \\
\hline $\mathrm{RF}_{\mathrm{ID}}, \mathrm{RF}_{\mathrm{CR}}, \mathrm{RF}_{\mathrm{D}}$ & 1.97 & 1.84 \\
\hline
\end{tabular}

Table 9. Tensile and junction strength before and after installation

\begin{tabular}{|c|c|c|c|}
\hline \multicolumn{2}{|c|}{ Property } & $W G-8$ & WKG-8 \\
\hline \multirow{2}{*}{$\begin{array}{c}\text { Tensile strength } \\
-M D(\mathrm{KN} / \mathrm{m})\end{array}$} & Original & 102.3 & 105.2 \\
\hline & Damaged & 79.9 & 84.2 \\
\hline \multicolumn{2}{|c|}{ Retention (\%) } & 78.1 & 80 \\
\hline \multirow{2}{*}{$\begin{array}{l}\text { Tensile strength } \\
\text {-CMD }(\mathrm{KN} / \mathrm{m})\end{array}$} & Original & 33.4 & 37.4 \\
\hline & Damaged & 30.8 & 25.3 \\
\hline \multicolumn{2}{|c|}{ Retention \% } & 92.2 & 67.7 \\
\hline \multirow{2}{*}{$\begin{array}{c}\text { Junction } \\
\text { strength }(\mathrm{KN} / \mathrm{m})\end{array}$} & Original & 5.5 & 12.3 \\
\hline & Damaged & 5.5 & 11 \\
\hline \multicolumn{2}{|c|}{ Retention (\%) } & 100 & 89 \\
\hline
\end{tabular}

Table 10. Junction strength reduction factor of installation damage combination with chemical degradation

\begin{tabular}{c|c|c}
\hline Reduction factor & WG-8 & WKG-8 \\
\hline $\mathrm{RF}_{\mathrm{ID}}, \mathrm{RF} \mathrm{CD}$ & 1.35 & 1.29 \\
\hline $\mathrm{RF}_{\mathrm{ID}}, \mathrm{RF}_{\mathrm{CD}}$ (junction) & 1.03 & 1.18 \\
\hline
\end{tabular}




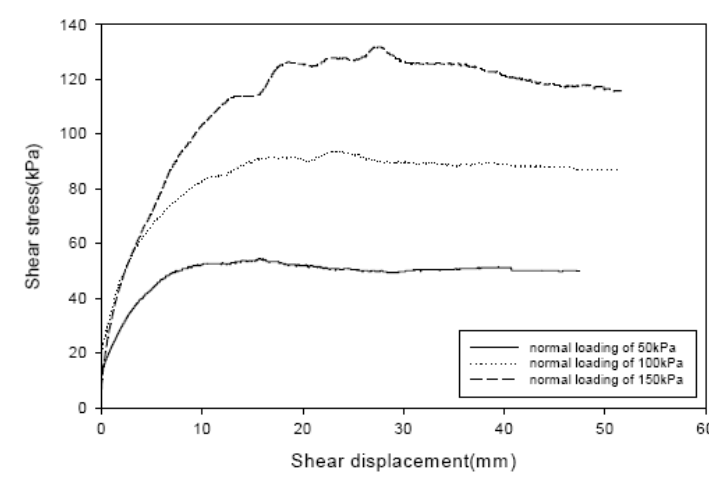

Fig. 15. Stress-strain behavior of soil / WBG-6 interfaces under different loadings

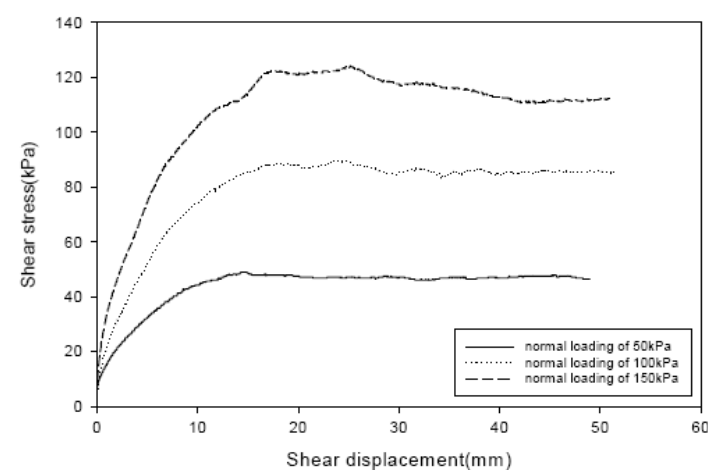

Fig. 16. Stress-strain behavior of soil /WBG-8 interfaces under different loadings

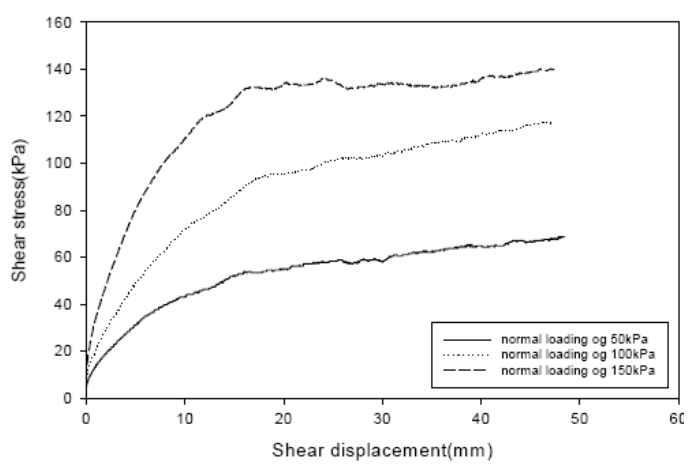

Fig. 17. Stress-strain behavior of soil / installed WBG-6 interfaces under different loadings

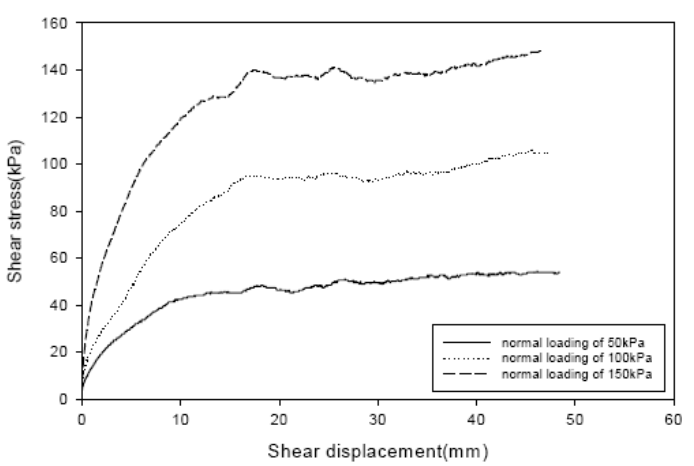

Fig. 18. Stress-strain behavior of soil / installed WBG-8 interfaces under different loadings mal stress before and after installation damage test. It was found that the shear strength was not relevant to the design strength of geogrids through direct shear test results. It was known that the peak value after installation damage test was almost similar to the one before installation damage test.

3.4 Failure Envelope, Frictional Coefficient and Friction Angle

Tables 13 - 14 show the frictional coefficient and friction angle values before and after installation damage test. In case of WBG- 6 , the maximum shear stress before and after installation damage test showed a similar frictional coefficient. On the other hand, WBG- 8 showed a greater frictional coefficient than the one before installation damage test. This is caused by the fact that the area in which the interaction force among soil particles occurs increases as the interaction force among soil particles in

Table 11. Shear stress of soil WBG-6 interface under different loadings

\begin{tabular}{c|c|c}
\hline \multirow{2}{*}{$\begin{array}{c}\text { Normal } \\
\text { loading }(\mathrm{kPa})\end{array}$} & \multicolumn{2}{|c}{ Peak stress $(\mathrm{kPa})$} \\
\cline { 2 - 3 } & Soil/WBG-6 & Soil/WBG-6 (ID) \\
\hline 50 & 54.47 & 53.92 \\
\hline 100 & 94.05 & 93.68 \\
\hline 150 & 131.81 & 136.17 \\
\hline
\end{tabular}

Table 12. Shear stress of soil WBG-8 interface under different loadings

\begin{tabular}{c|c|c}
\hline \multirow{2}{*}{$\begin{array}{c}\text { Normal } \\
\text { loading }(\mathrm{kPa})\end{array}$} & \multicolumn{2}{|c}{ Peak stress (kPa) } \\
\cline { 2 - 3 } & Soil/WBG-8 & Soil/WBG-8 (ID) \\
\hline 50 & 49.02 & 48.47 \\
\hline 100 & 89.32 & 95.32 \\
\hline 150 & 124.18 & 139.98 \\
\hline
\end{tabular}

Table 13. Frictional coefficient and frictional angle of WBG-6

\begin{tabular}{c|c|c}
\hline Geogrids & Frictional coefficient & Frictional Angle \\
\hline Original & 0.91 & 42.3 \\
\hline Damaged & 0.93 & 42.9 \\
\hline
\end{tabular}

Table 14. Frictional coefficient and frictional angle of WBG-8

\begin{tabular}{c|c|c}
\hline Geogrids & Frictional coefficient & Frictional Angle \\
\hline Original & 0.86 & 40.7 \\
\hline Damaged & 0.94 & 43.2 \\
\hline
\end{tabular}


pores that are the morphological property of geogrids works and soil particles are condensed by damages on the surface of geogrids due to installation damage test at the same time. Besides, the PVC coated geogrid surface is smooth but it can be said that larger frictional force occurred as roughness of the surface took place after installation damage test.

\section{Conclusion}

(1) Long-term property of geogrids was evaluated considering combined effect of reduction factors for the following aims: (a) evaluation of long-term allowable tensile strength considering combined effect of reduction factors (b) interpretation of the geogirds junction strength by installation damage and chemical degradation (c) interpretation of shear behavior of geogrids through index installation damage testing.

(2) Effect of three reduction factors such as installation damage, chemical degradation and creep which affect the long-term properties of geogrids were tested and compared. Chemical resistance decreased followed by installation damage especially at high alkali conditions showed large reduction in strength. But there was no change in $\mathrm{pH}=9$ at $50^{\circ} \mathrm{C}$ in soil and less than $10 \%$ of decrease showed in gravel. It can be predicted that in real environment chemical degradation followed by installation damage is very limited. Combined reduction factor of installation damage and creep showed 1.61 and 1.76 in IDS and IDG respectively which are lower than calculated values $(1.69,1.97)$. When gravel was used as filling material, it showed large reduction factor and the combination effect was also large, which largely reduced uncertainty of allowable tensile strength.

Tested total reduction factors showed 1.59 and 1.84 in IDS and IDG respectively, which are much lower than calculated reduction factors according to GRI GG-4 (1.69, 1.97).

(3) Tensile strength reduction factors of WG-8 and WKG-8 showed 1.35 and 1.29 respectively after installation damage and chemical degradation while junc- tion strength reduction factors showed 1.03 and 1.18 respectively. Junction strength reduction factor of geogrids depends on the type of junctions. Woven geogrid showed lower reduction factor than that of warp knitted geogrids due to pull-out mechanism. Junction is the weakest part in geogrid but it was found that junction strength reduction factor was much lower than tensile strength reduction factor.

(4) Results of direct shear test showed that post-peak strength of original geogrids reduced after peak strength. However, post-peak strength of installation damaged geogrids showed the tendency of gradually increasing. Frictional angle of WBG-6 and WBG-8 increased by 0.6 and 2.5 after installation damage.

(5) In conclusion, change of junction and shear strength are limited by reduction factors. GRI GG-4 is a conservative test method, includes sufficient reduction factors to be considered to predict long-term properties of geogrids. Therefore it is proposed that calculated allowable tensile strength from GRI GG-4 test method can be directly used to design geogrid -reinforced soil structures and it seems that additional safety factor is not needed.

(6) Soil and gravel used in this experiment represent general condition and worst condition respectively, but these can not present all cases of real site condition. Laboratory installation damage can not provide a complete "blue print" of the installation damage susceptibility and $\mathrm{NaOH}$ solution can not entirely represent site environment. So, it requires field installation damage test and actual solution to test combination effect.

\section{References}

1. Allen, T. M. and Bathurst, R. J. (1996), "Combined allowable strength reduction factor for geosynthetic creep and installation damage", Geosynthetics International, Vol. 3, No. 3, pp. 407-439.

2. Allen, T. M. and Bathurst, R. J. (2002), "Long-term performance of geosynthetic walls", Geosynthetics International, Vol. 9, No. 5-6, pp. 575-578.

3. ASTM D4595. Standard Test Method for Tensile Properties of Geotextiles by the Wide Width Strip Method, ASTM International, West Conshohocken, PA.

4. ASTM D5321. Standard Test Method for Determining the 
Coefficient of Soil and Geosynthetic or Geosynthetic and Geosynthetic Friction by the Direct Shear Method, ASTM International, West Conshohocken, PA

5. Berg, R. R., Allen and Bell, J. R. (1998), "Design procedure for reinforced soil walls-A historical perspective", Proc. of 6th IC ongeosynthetics, pp. 491-496.

6. Billing, J. W., Greenwood, J. H. and Small, G. D. (1990), "Chemical mechanical durability of geotextiles", proc. of the 4th international Conference on Geotextiles, Geomembranes and Related Products, pp. 621-626.

7. Cho, S. D., Lee, K. W., Cazzuffi, Daniele A. and Jeon, H. Y. (2006), "Evaluation of combination effects of installation damage and creep behavior on long-term design strength of geogrids", Polymer testing, Vol. 25, pp. 819-828.

8. GRI standard - GG4. Standard Practice for Determination of the Long-Term Design Strength of (a) Stiff and (b) Flexible Geogrids.
9. Hsieh, C., Wu, J. H., Lin, C. K. and Hsieh, M. (2000), "The study of the installation damage of flexible geogrids". Proc. of the 2nd European Geosynthetics Conference, Bologna, pp. 889-893.

10. ISO 10722-1. Geotextiles and geotextile-related products-Procedure for simulating damage during installation.

11. Koerner, R. M. (2005), Designing with Geosynthetics, 5th edition, Person Education Inc., NewJersey, pp. 332-348.

12. Lawson, C. R. (1986), "Geosynthetics in soil reinforcement", Proc of symposium on geotextiles in civil engineering, Institution of engineers Australia, Newcastle, pp. 1-35.

13. Task Force \#27. (1991), Guidelines for the design of mechanically stabilized earth walls, AASHTO-AGC-ARTBA Joint committee, Washington, DC.

14. Zornberg, J. G. and Mitchell, J. K. (1994), "Reinforced soil structures with poorly draining backfills", Geosynthetics International, Vol. 1, No. 2, pp. 103-147. 